\title{
Main causes of chicken carcass condemnations in Espírito Santo, Brazil
}

\section{Principais causas de condenações de carcaça de frango no Espírito Santo, Brasil}

\author{
Matheus Joaquim dos Santos Candido ${ }^{1 *}$; Surama Freitas Zanini2; Marcus de \\ Freitas Ferreira ${ }^{2}$; Filipe Augusto Coimbra de Araujo'; Alan Paulo Moreira Teixeira3; \\ Raoni Cezana Cipriano4; Maria Augusta Pires da Luz Chieppe Moulim ${ }^{5}$
}

\section{Highlights}

The main causes of condemnations have a non-pathological origin.

Causes of condemnations by SIF are greater than those recorded by the SIE.

Major partial condemnations by SIF: bruises, dermatosis, contamination and myopathy.

SIF's condemnations: hemorrhagic viscera, cachexia, ascites and repulsive appearance.

SIE's condemnations: bruises/fractures, contamination, cellulitis and ascites.

\begin{abstract}
Brazil is the third largest producer and the main exporter of chicken meat in the world. In 2019, it produced approximately 13.245 million tons of the product, generating more than six million dollars. According to the Poultry Association of the state of Espírito Santo, broiler production is carried out by 28 independent producers/companies, three integrator businesses, 42 integrated producers and seven slaughterhouses (structures with SIF, SIE/SISBI or SIE certification). Despite the growth of this sector, problems persist regarding the quality of carcasses and the number of condemnations. From the sanitary and industrial point of view, all products of animal origin must undergo prior inspection. The present study was developed using data generated by the Federal Inspection Service (Serviço de Inspeção Federal, SIF) and the State Inspection Service (Serviço de Inspeção Estadual, SIE). The main causes of condemnation of birds as inspected by SIF represented $9.26 \%$ of the slaughtered birds. Total condemnations corresponded to $1.35 \%$. Overall, this study recorded a greater number of condemnations of non-pathological origin. In conclusion, there was consistency in the reasons why these products were condemned. Bruises/fractures and contamination

1 Veterinary Medicine Students, Federal University of Espírito Santo, UFES, Alegre, ES, Brazil. E-mail: mcandido0352@ gmail.com; felipeaugls@hotmail.com

2 Drs. in the Department of Veterinary Medicine, UFES, Alegre, Brazil. E-mail: smzanini@yahoo.com.br; marcusufes@ gmail.com

${ }^{3}$ Veterinarian, Animal Origin Products sub Manager in Institute of Agricultural and Forestry Defense, IDAF, Vitória, ES, Brazil. E-mail: alan.teixeira@idaf.es.gov.br

${ }^{4}$ Veterinarian, Health Defense and Animal Inspection Manager, IDAF, Vitória, ES, Brazil. E-mail: rcipriano@idaf.es.gov.br

5 Veterinarian Graduate, UFES, Alegre, ES, Brazil. E-mail: maugustachieppe@gmail.com

* Author for correspondence
\end{abstract}

Received: July 06, 2020 - Approved: Oct. 13, 2020 
were the most frequent causes according to both inspection services (SIF and SIE), indicating a common problem on the slaughter and inspection lines.

Key words: Broilers. Condemnation. Control. Inspection.

\section{Resumo}

O Brasil é o terceiro maior produtor e o principal exportador de carne de frango do mundo. Em 2019, produziu aproximadamente 13,245 milhões de toneladas, faturando mais de seis milhões de dólares. Segundo a Associação dos Avicultores do Estado do Espírito Santo, a avicultura de corte conta com 28 produtores/empresas independentes, três integradoras, 42 integrados além de 7 abatedouros (estruturas com SIF, SIE/SISBI ou SIE). Embora tenha havido crescimento neste setor, ainda persistem problemas relacionados com a qualidade das carcaças e com o quantitativo de condenações. Sob o ponto de vista sanitário e industrial todos os produtos de origem animal devem receber fiscalização prévia. O presente trabalho foi desenvolvido mediante levantamento de dados gerados pelo Serviço de Inspeção Federal (SIF) e pelo Serviço de Inspeção Estadual (SIE). As principais causas de condenações de aves inspecionadas pelo SIF representaram $9,26 \%$ das aves abatidas. Para as condenações totais foi registrado o percentual de 1,35\%. Este estudo registrou, no geral, um maior número de condenações de origem não patológica. Conclui-se que houve uma constância nas razões pelas quais esses produtos sofreram condenações. As contusões/fraturas e contaminações foram as de maior ocorrência, em ambos os Serviços de Inspeção (SIF e SIE), indicando um problema comum na linha de abate e inspeção.

Palavras-chave: Condenação. Fiscalização. Frango de corte. Inspeção.

\section{Introduction}

Chicken meat stands out worldwide for representing the combination of a high-quality food and a low price. According to the Brazilian Animal Protein Association (Associação Brasileira de Proteína Animal [ABPA], 2020), Brazil is among the top chicken producing and exporting countries. In 2018, the country held its first place in exports of chicken meat and reached second in production, with a total of 12.86 million tons (ABPA, 2019). In 2019, the country hit its own record of 13.245 million tons of chicken produced a growth of around $2.99 \%$, making it the third largest world producer, with a per capita consumption of $42.84 \mathrm{~kg}$ and exports above 4,214 thousand tons. As such, it held its first place in this last classification, generating an additional six million Brazilian reais with the product (ABPA, 2020). About $68.0 \%$ of all chicken meat produced in Brazil is destined for the supply of the domestic market and $32.0 \%$ is exported, mostly in the form of cuts $(67 \%)$ and whole (26\%), to regions such as Asia, Middle East and Africa. In this respect, the state of Espírito Santo stands out as one of the main exporters (ABPA, 2020). According to the Poultry Association of the state of Espírito Santo (Associação dos Avicultores do Estado do Espírito Santo, AVES), broiler production is developed by 28 independent producers/ companies, three integrator businesses and 42 integrated producers in addition to seven slaughterhouses (structures under SIF, SIE/ SISBI or SIE certification). In the State, the municipality of Domingos Martins ranks first in broiler production with $26.22 \%$ of the state production, followed by the municipalities of 
Marechal Floriano (24.56\%), Linhares (20.25\%) and Venda Nova do Imigrante (11.68\%), with the remaining municipalities accounting for 17.29\% (Associação dos Avicultores do Estado do Espírito Santo [AVES], 2018). Partial data from the agricultural census released by the Brazilian Institute of Geography and Statistics (Instituto Brasileiro de Geografia e Estatística [IBGE], 2017) indicate that, between 2006 and 2017, poultry production in Espírito Santo grew by $115 \%$. According to AVES, the gross revenue of the broiler production sector was over 560 million Brazilian reais.

Despite the growth of this sector, problems persist regarding the quality of carcasses and the number of condemnations, which raise a red flag due to the significant losses occurring in this sector in Espírito Santo.

In Brazil, the most widely used broiler strain is Cobb, most likely due to its greater growth potential, higher maturity rate and lower slaughter age, in addition to the pale pink color of its meat that guarantees its acceptance in the market (Santos et al., 2005). Other authors consider it the second best strain in (clean) carcass weight, bone-in and boneless breast, and boneless legs, only behind the Ross strain (Flemming, Janzen, \& Endo, 1999). Despite the differences between the available commercial strains in the country, all have high carcass yields, with the final outcome depending on the genetic selection applied (Moreira et al., 2003).

From the sanitary and industrial point of view, all products of animal origin must undergo prior inspection, whether or not they are edible, include plant-based products and are prepared, processed, handled, received, in transit, packaged and/or stored (Lei $n^{\circ} 1.283$, 1950). The Ministry of Agriculture, Livestockand Supply (MAPA) is responsible for the inspection of animal products sold between states orland internationally, through the Federal Inspection Service (Serviço de Inspeção Federal, SIF). Products with the described characteristics and which are distributed between municipalities are under the responsibility of the agricultural departments of the States, the Federal District and the Territories, and subject to the State Inspection Service (Serviço de Inspeção Estadual, SIE). As for sales within the municipality, the agriculture departments of the municipalities are responsible for inspection, under the so-called Municipal Inspection Service (Serviço de Inspeção Municipal, SIM). All of these are aimed at ensuring the quality of these products for the domestic and foreign markets (Lei n. 7.889, 1989). Inspection by the SIF agent at broiler slaughterhouses, for instance, takes place permanently in two stages, namely, antemortem and postmortem. Antemortem inspection has the purpose of preventing the slaughter of animals with a replete gastrointestinal tract and, consequently, possible contaminations during processing (Portaria $n^{\circ} 210,1998$ ). To avoid this type of condemnation, birds must be fasted for 6 to $8 \mathrm{~h}$ (Ebling \& Basurco, 2016). Among the main factors that lead to condemnation by SIF in the state of Rio Grande do Sul are cachexia, repulsive appearance, cellulitis, bruises/fractures and contamination (Ferreira, Sesterhenn, \& Kindlein, 2012).

In view of the lack of compilation of the information, interpretation and dissemination of results of great impact on the reality of Espírito Santo, this study was developed to determine the main causes of condemnation (partial and total) during the postmortem inspection of carcasses of broilers slaughtered at slaughterhouses inspected by SIF and SIE in the state of Espírito Santo. 


\section{Material and Methods}

The present study was developed through a survey of data generated by SIF and SIE of Espírito Santo. The data include information from four slaughterhouses regularly registered with $\mathrm{SIE}$, located in the municipalities of Cariacica, Marechal Floriano, Santa Maria de Jetibá and Vila Velha; and two registered with SIF, located in the municipalities of Linhares and Castelo. The establishments inspected by SIF received birds from 14 municipalities in the State, namely, Alfredo Chaves, Brejetuba, Cachoeiro de Itapemirim, Castelo, Conceição do Castelo, Domingos Martins, Guarapari, Jaguaré, Linhares, Marechal Floriano, Muniz Freire, Sooretama, Vargem Alta and Venda Nova do Imigrante. This data collection took place in the period from January 2018 to December 2019.

The postmortem inspection procedure for chickens is carried out in accordance with the Regulation for Industrial and Sanitary Inspection of Animal Products (Decreto $n^{\circ}$ 9.013, 2017) and Ordinance No. 210 of November 1998 of MAPA. The inspection is performed by visual and olfactory examination and by palpating the carcasses and their respective viscera, on the so-called "inspection lines" ("A" - internal examination of the carcass - opening and viewing of the coelomic cavity; "B" - examination of viscera; and " $\mathrm{C}$ " - external examination of the carcass).

Causes of condemnation (partial and total) as determined by SIF and SIE under Ordinance 2010/98 are abscess, airsacculitis, arthritis, repulsive appearance, cachexia, cellulitis, colibacillosis, contamination, bruises/ fractures, dermatosis, overscalding, delayed evisceration, neoplasms, salpingitis, ascites, hemorrhagic syndrome and septicemia.
In the analysis of the condemnations at slaughterhouses registered only with SIE, improper bleeding procedure and other causes are identified. In the analysis of condemnations at slaughterhouses registered only with SIF, ascites, bloody meat, coligranulomatosis, abnormal color, technological flaws, skin lesion, inflammatory lesion, traumatic lesion, myocarditis, myopathy, dorsal cranial myopathy, nephritis, hemorrhagic viscera and pericarditis were considered.

The obtained information was used to rank the causes of partial and total condemnations by the respective inspection services according to the changes found and frequency of occurrence in the studied period as well as compare them with other data described in the literature of other Brazilian states.

Data were compiled on a nosographic map with the following criteria: diagnosis (pathologies) and year of evaluation with respective partial and total condemnations. Subsequently, the four main condemnations by SIE and SIF were analyzed. Statistical analysis was performed descriptively using the relative and absolute frequencies of condemnations, whose results are presented in the form of tables.

\section{Results and Discussion}

The main causes of poultry condemnation at slaughterhouses can have health or management origins or may occur during slaughter and processing (Maschio \& Raszl, 2012). Tables 1 and 2 show the total number of birds slaughtered in establishments inspected by SIF and SIE, with the respective partial and total condemnation rates. From 
January 2018 to December 2019, a total of 73.547 million broilers were slaughtered in establishments inspected by SIF in Espírito Santo. In facilities under State Inspection, the number of birds slaughtered reached 32.548 million. Of the total number of birds inspected by SIF, 6,677,872 exhibited some type of partial condemnation (Table 3), which represented $9.26 \%$ of the slaughtered birds. A total of 977,361 cases of total condemnation (Table 4) (1.35\%) was recorded. When total and partial condemnations are added up, $7,655,233$ chickens were found to have some deviation, which corresponds to slightly over $10 \%$ of the total number of birds slaughtered by facilities under SIF. Maschio and Raszl (2012) and Ferreira et al. (2012) reported that the partial condemnation rate was higher than the total condemnation rate, as observed in this study. In the slaughterhouses inspected by SIF, the partial condemnation rate reached $87.81 \%$, whereas the total was $12.77 \%$, which are lower than the $97.22 \%$ (partial) and higher than the $2.78 \%$ (total) found by Maschio and Raszl (2012). The criteria for these condemnations were based on Ordinance No. 210 of November 1998 of MAPA. These values refer only to postmortem condemnations and do not include animals that died on the farms or during transport for SIF assessment. The results obtained in the present study (Table 1) are above the average partial and total condemnations reported by Paschoal, Otutumi and Silveira (2012) and Goscinscki (2016), which ranged from 7 to $8 \%$. As for the data on condemnations (partial and total) of broilers slaughtered at establishments inspected by SIE, 2,054,937 cases (6.30\%) had some type of postmortem condemnation (Table 5). These results differ from the findings published by Dias et al. (2017), who observed that, of a total of 515,582 thousand birds slaughtered in a slaughterhouse under SIF in Espírito Santo, 87,423 thousand (16.95\%) showed some type of postmortem condemnation. It is worth noting that until 2019, the SIE in Espírito Santo did not provide data on condemnations categorized as partial and total.

Table 1

Total and partial condemnations of broiler carcasses in establishments inspected by the Federal Inspection Service (SIF) of the state of Espírito Santo, between January 2018 and December 2019

\begin{tabular}{cccccc} 
Period & \multicolumn{2}{c}{ Partial condemnations } & \multicolumn{2}{c|}{ Total condemnations } & $\begin{array}{c}\text { Number of slaughtered } \\
\text { chickens }\end{array}$ \\
\cline { 2 - 6 } & $\mathrm{N}$ & $\%^{*}$ & $\mathrm{~N}$ & $\%$ & $\mathrm{~N}$ \\
\hline 2018 & $2,888,375$ & 8.15 & 653,482 & 1.84 & $35,453,511$ \\
2019 & $3,946,876$ & 10.36 & 323,879 & 0.85 & $38,094,325$ \\
Total & $6,677,872$ & 9.26 & 977,361 & 1.35 & $73,547,836$ \\
\hline
\end{tabular}

* Calculation based on the number of slaughtered birds. 
Table 2

Condemnations of broiler carcasses in establishments inspected by the State Inspection Service (SIE) of the state of Espírito Santo, between January 2018 and December 2019

\begin{tabular}{cccc} 
& \multicolumn{2}{c}{ Condemnations (partial and total) } & Number of slaughtered chickens \\
\cline { 2 - 4 } Period & $\mathrm{N}$ & $\%^{*}$ & $\mathrm{~N}$ \\
\hline 2018 & 824,685 & 5.27 & $15,645,171$ \\
2019 & $1,230,252$ & 7.32 & $16,813,091$ \\
\hline Total & $2,054,937$ & 6.30 & $32,458,262$ \\
\hline
\end{tabular}

* Calculation based on the number of slaughtered birds.

\section{Table 3}

Changes in the broiler carcass as assessed by the Federal Inspection Service (FIE), suggestive of condemnation (partial and total), and their respective number, between January 2018 and December 2019

\begin{tabular}{|c|c|c|c|}
\hline Diagnosis & $\mathrm{N}$ & $\% *$ & $\%$ \%* \\
\hline Abscess & 114,727 & 0.15 & 1.72 \\
\hline Airsacculitis & 8,532 & 0.01 & 0.12 \\
\hline Arthritis & 110,130 & 0.14 & 1.65 \\
\hline Ascites & 10,450 & 0.01 & 0.15 \\
\hline Repulsive appearance & 9,674 & 0.01 & 0.14 \\
\hline Cachexia & 189 & 0.00 & 0.00 \\
\hline Bloody meat & 5 & 0.00 & 0.00 \\
\hline Cellulitis & 181,618 & 0.24 & 2.72 \\
\hline Colibacillosis & 38,051 & 0.05 & 0.56 \\
\hline Contamination & 375,222 & 0.51 & 5.61 \\
\hline Bruises & $4,357,287$ & 5.92 & 65.25 \\
\hline Dermatosis & $1,015,266$ & 1.38 & 15.19 \\
\hline Overscalding & 94 & 0.00 & 0.00 \\
\hline Technological flaws & 38 & 0.00 & 0.00 \\
\hline Skin lesions & 863 & 0.00 & 0.01 \\
\hline Inflammatory lesions & 89,331 & 0.12 & 1.34 \\
\hline Myocarditis & 664 & 0.00 & 0.00 \\
\hline Dorsal cranial myopathy & 47,335 & 0.06 & 0.71 \\
\hline Myopathy & 218,721 & 0.29 & 3.28 \\
\hline Neoplasia & 5 & 0.00 & 0.00 \\
\hline Pericarditis & 23,871 & 0.03 & 0.35 \\
\hline Salpingitis & 18,560 & 0.02 & 0.28 \\
\hline
\end{tabular}

* Calculation based on the number of slaughtered birds.

** Calculation based on the number of partially condemned birds. 
Table 4

Changes in the broiler carcass as assessed by the State Inspection Service (SIE), suggestive of condemnation (partial and total), and their respective number, between January 2018 and December 2019

\begin{tabular}{|c|c|c|c|}
\hline Diagnosis & $\mathrm{N}$ & \%* & $\%$ \%* \\
\hline Repulsive appearance & 68,500 & 0.09 & 7.00 \\
\hline Airsacculitis & 15 & 0.00 & 0.00 \\
\hline Muscle changes & 12 & 0.00 & 0.00 \\
\hline Arthritis & 1 & 0.00 & 0.00 \\
\hline Cachexia & 97,755 & 0.13 & 10.00 \\
\hline Bloody meat & 6,400 & 0.00 & 0.65 \\
\hline Cellulitis & 149 & 0.00 & 0.01 \\
\hline Colibacillosis & 4216 & 0.00 & 0.43 \\
\hline Coligranulomatosis & 19 & 0.00 & 0.00 \\
\hline Abnormal color & 353 & 0.00 & 0.03 \\
\hline Contamination & 2 & 0.00 & 0.00 \\
\hline Bruises & 22 & 0.00 & 0.00 \\
\hline Dermatosis & 354 & 0.00 & 0.04 \\
\hline Overscalding & 104,078 & 0.14 & 1.64 \\
\hline Delayed evisceration & 2,062 & 0.00 & 0.21 \\
\hline Technological flaws & 63 & 0.00 & 0.00 \\
\hline Traumatic lesions & 2 & 0.00 & 0.00 \\
\hline Myopathy & 2,078 & 0.00 & 0.21 \\
\hline Dorsal cranial myopathy & 6,537 & 0.00 & 0.66 \\
\hline Nephritis & 964 & 0.00 & 0.09 \\
\hline Neoplasia & 454 & 0.00 & 0.04 \\
\hline Salmonellosis & 231 & 0.00 & 0.02 \\
\hline Salpingitis & 7,529 & 0.01 & 0.77 \\
\hline Septicemia & 1,433 & 0.00 & 0.14 \\
\hline Ascites & 85,372 & 0.11 & 8.73 \\
\hline Hemorrhagic syndrome & 15 & 0.00 & 0.00 \\
\hline Hemorrhagic viscera & 574,305 & 0.78 & 58.76 \\
\hline
\end{tabular}

* Calculation based on the number of slaughtered birds.

** Calculation based on the number of totally condemned birds. 
Table 5

Changes in broiler carcasses as assessed by the State Inspection Service (SIE), suggestive of condemnation (partial and total), and their respective number, between January 2018 and December 2019

\begin{tabular}{|cccc|}
\hline Diagnosis & $\mathrm{N}$ & $\%^{*}$ & $\%^{* *}$ \\
\hline Abscess & 88 & 0.00 & 0.00 \\
\hline Airsacculitis & 9,809 & 0.03 & 0.47 \\
\hline Arthritis & 411 & 0.00 & 0.02 \\
\hline Repulsive appearance & 27,904 & 0.08 & 1.36 \\
\hline Cachexia & 29,706 & 0.09 & 3.45 \\
\hline Cellulitis & 70,319 & 0.22 & 0.28 \\
\hline Colibacillosis & 5,738 & 0.01 & 10.74 \\
\hline Contamination & 220,715 & 0.67 & 67.55 \\
\hline Bruises/fractures & $1,388,161$ & 4.28 & 0.51 \\
\hline Dermatosis & 10,527 & 0.03 & 0.84 \\
\hline Overscalding & 17,425 & 0.05 & 0.63 \\
\hline Delayed evisceration & 12,963 & 0.03 & 0.00 \\
\hline Neoplasias & 169 & 0.00 & 1.34 \\
\hline Salpingitis & 27,460 & 0.08 & 0.48 \\
\hline Improper bleeding procedure & 9,780 & 0.06 & 0.72 \\
\hline Septicemia & 14,811 & 0.03 & 1.98 \\
\hline Ascites & 40,758 & 0.12 & 0.00 \\
\hline Hemorrhagic syndrome & 0 & 0.00 & 3.43 \\
\hline Died during transport & 70,518 & 0.21 & 4.75 \\
\hline Other causes & 97,675 & 0.30 & \\
\hline & & & \\
\hline
\end{tabular}

* Calculation based on the number of slaughtered birds.

** Calculation based on the number of condemned birds (partial and total).

Table 6 shows the main changes considered partial condemnations by the SIF and the respective numbers of condemnations per diagnosis. The most frequent were bruises $(5.92 \%)$, dermatosis $(1.38 \%)$, contamination $(0.51 \%)$ and myopathies (0.29\%). These data do not corroborate the information found by Maschio and Raszl (2012) and by Ferreira et al. (2012), who found arthritis and cellulitis, respectively, as prominent causes, which was not observed in the current study. Bruises/ fractures and contamination lead the indices in studies, even when these are carried out in different regions of the country. The origins of these condemnations are extrinsic to birds and consist of problems of handling and operational adjustments during the phases of production, slaughter and processing, as described by Mendes and Komiyama (2011) and Rossi (2020). As an example, bruises can occur due to improper handling in picking, loading and transporting the animals. Kettlewell and Turner 
(1985) reported that bruises occur because birds are still hung manually and this practice depends directly on workforce, who may not be properly trained. Rossi (2020) also described that the wings and drumstick are the main affected regions, presenting a hemorrhagic aspect macroscopically, with a bright red, dark or greenish color, depending on the evolution of the fracture, and that there may be conditions that contribute to the appearance of the lesion. In addition, according to Leandro, Rocha, Stringhini and Fortes (2001), picking the birds by the neck results in a higher incidence of bruises than by grabbing by their back.

\section{Table 6}

Main causes of partial condemnations of broilers in establishments in Espírito Santo inspected by the Federal Inspection Service (SIF) between January 2018 and December 2019

\begin{tabular}{ccccccccc}
\multirow{2}{*}{ Year } & \multicolumn{2}{c}{ Bruises } & \multicolumn{2}{c}{ Dermatosis } & \multicolumn{2}{c}{ Contamination } & \multicolumn{2}{c|}{ Myopathy } \\
\cline { 2 - 8 } & $\mathrm{N}$ & $\%^{*}$ & $\mathrm{~N}$ & $\%^{*}$ & $\mathrm{~N}$ & $\%^{*}$ & $\mathrm{~N}$ & $\%{ }^{*}$ \\
\hline 2018 & $2,042,754$ & 70.72 & 441,260 & 15.28 & 117,861 & 4.08 & 30,408 & 1.05 \\
\hline 2019 & $2,314,533$ & 58.64 & 574,006 & 14.54 & 257,561 & 6.53 & 188,313 & 4.77 \\
Total & $4,357,287$ & 64.68 & $1,015,266$ & 14.91 & 369,422 & 5.31 & 218,721 & 2.91
\end{tabular}

${ }^{*}$ Calculation based on the number of partially condemned birds.

Dermatoses, on the other hand, refer to a group of diseases and changes that can occur in the skin tissue, such as increased skin thickness, color changes and surface alterations with the appearance of erosions, ulcers and nodules (Saif, 2003; Oliveira, Andrade, Armendaris, \& Bueno, 2016). The appearance of this pathology is related to reuse of litter (Gundim, Rodrigues, Blanca, Coleto, \& Medeiros, 2015), heavy chickens, excessive litter moisture and high stocking rates (Rossi, 2020).

Contaminations would be due to a lack of regulation of the evisceration machinery, which ends up causing the viscera to rupture and their content to leak, or non-uniformity of the lot, with birds of different sizes (Maschio \& Raszl, 2012; Rossi, 2020). Contamination may be of fecal or biliary origin, in the latter case stemming from a rupture of the gallbladder, which can be located both on the surface of the carcass and internally. It is also important to mention that fecal contamination represents a high risk to the health of the consumer, since most pathogens are found in the intestine. An important pathogen in this group is Campylobacter jejuni, which is reported to occur at a high frequency in other countries and which is underreported in Brazil due to low outbreaks, besides Salmonella spp (Rossi, 2020). To prevent this type of occurrence, it is also necessary to empty the intestine in the preslaughter period and it is recommended that water and feed not be removed simultaneously (Mendes \& Komiyama, 2011).

In the data provided by MAPA, condemnation due to myopathy is separated into two categories, as described in Table 4: myopathy itself and dorsal cranial myopathy. This pathology can be defined by a reduction of 
the blood supply and consequent appearance of alterations such as degeneration, fibrosis and necrosis of the muscle tissue. It is worth emphasizing that the condition is not linked to any infectious agent (Bilgilie \& Hess, 2008). As stated by Hoving-Bolink, Kranen, Klont Gerritsen and Greef (2000), chickens that have a higher breast muscle yield tend to show problems related to low oxygenation, since there is reduced capillary density. Agreeing with this idea, Joiner, Hamlin, Lien and Bilgili (2014) reported that with the advance of age, muscle fibers tend to enlarge while blood capillaries reduce in quantity, in association with marginalization of vascular support on myofibers, which is important for fastgrowing animals. The pectoral muscle of birds is mostly made up of white fibers. Therefore, their muscle fibers have a larger diameter and are surrounded by smaller capillaries, consequently having less oxygen than red fibers, which constitutes an adaptation to anaerobic metabolism (Santiago, 2001). Due to the characteristics of this musculature, some factors such as rapid growth and increased pectoral muscle resulting from selective breeding carried out over the last few years allow the development of muscle injuries as a result of reduced supply of nutrients and oxygen and slow removal of the lactic acid produced (Hoving-Bolink et al., 2000). Although myopathy has been described by Assis, Sabino, Silva and Fontes (2019) as a real problem for chicken slaughter establishments, there is a shortage of studies reporting this pathology in prominence.

Table 7 shows the most frequent changes that led to total condemnations by SIF and the respective numbers of condemnations per diagnosis. Hemorrhagic viscera $(0.78 \%)$, cachexia $(0.13 \%)$, ascites $(0.11 \%)$ and repulsive appearance $(0.09 \%)$ stood out. Our results partially corroborate the findings of Maschio and Raszl (2012), who reported that ascites $(0.06 \%)$, colibacillosis $(0.04 \%)$ and improper bleeding procedure $(0.03 \%)$ were the main causes of total condemnations.

According to Mendes and Komiyama (2011) and Ebling and Basurco (2016), hemorrhagic viscera fall within the causes related to slaughter and processing. This occurrence may be linked to problems during the bleeding procedure due to deregulation of the stunning equipment, whose amperage and voltage should be adjusted according to the weight of the lots (Mendes \& Komiyama, 2011).

Table 7

Main causes of total condemnation of broilers in establishments in Espírito Santo inspected by the Federal Inspection Service (SIF) between January 2018 and December 2019

\begin{tabular}{ccccccccc}
\multirow{2}{*}{ Year } & \multicolumn{2}{c}{ Hemorrhagic viscera } & \multicolumn{2}{c}{ Cachexia } & \multicolumn{2}{c}{ Ascites } & \multicolumn{2}{c}{ Repulsive appearance } \\
\cline { 2 - 8 } & $\mathrm{N}$ & $\%^{*}$ & $\mathrm{~N}$ & $\%^{*}$ & $\mathrm{~N}$ & $\%^{*}$ & $\mathrm{~N}$ & $\%^{*}$ \\
\hline 2018 & 496,569 & 75.99 & 55,549 & 8.50 & 39,527 & 6.05 & 35,652 & 5.46 \\
\hline 2019 & 77,736 & 24.00 & 42,206 & 13.03 & 45,845 & 14.15 & 32,848 & 10.14 \\
Total & 574,305 & 50.00 & 97,755 & 10.77 & 85,372 & 10.10 & 68,500 & 7.80
\end{tabular}

* Calculation based on the number of totally condemned birds. 
Cachexia, also knownas "malabsorption syndrome" or "runting stunting syndrome", has its destination dictated in accordance with annex IX, article 232, Ordinance No. 210 of November 1998 of MAPA, which informs that all "cachectic animals should be condemned, regardless of the causes linked to the malnutrition process". Kotler (2000) highlights the role of malnutrition as an inducer of destabilization of the immune system and predisposition to the emergence of infectious diseases. A poor diet may be associated with various situations, such as environmental temperature, wind, lighting program, toxins, anxiety and pathogens (Tinôco, 2001). These factors may be responsible for the production of cytokines capable of stimulating proteolysis. The percentage found in this study $(0.13 \%)$ is higher than the $0.06 \%$ found by Almeida, Assis, Mendonça and Rolim (2017) in the northeast region of Brazil. Even though cachexia is one of the main causes of total condemnations, it was found at relatively low values, as in the study of Ferreira et al. (2012) (around 0.17\%) and Paschoal et al. (2012) (around 0.026\%). Other researchers, e.g., Maschio and Raszl (2012), do not even describe cachexia as a prominent cause, as it represented $0.001 \%$ of the annual slaughter.

Carcasses are classified as repulsive when they have a poor appearance, exhibit an abnormal color or exude medicinal, fecal, sexual or other odors deemed abnormal, and should be considered in the condemnation of birds. This includes game birds that display putrefactive changes, giving off a sulfurousammoniacal odor, revealing gas crepitation on palpation or changes in muscle color (Decreto $n^{\circ}$ 9.013, 2017). The most frequent forms of alteration observed in the carcasses of chickens is a change in the color throughout the carcass musculature to a dark red shade, with a hard consistency and dry appearance, also known as DFD (dark, firm, dry) or PSE (pale, soft, exudative) meat, neither of which poses risks to human health. Both abnormalities are associated with chronic and acute preslaughter stress in broilers (Langer, 2007).

The current data are partially similar to those found by Paschoal et al. (2012) in a slaughterhouse located in the northwest of Paraná. In their study, the authors did not observe hemorrhagic viscera or ascites as the main causes of condemnation. However, repulsive appearance (47.33\%) was the most important cause of condemnation in their study, whereas in the current investigation this condition was observed in $7.80 \%$ of the total fully condemned birds. In the survey carried out by Ferreira et al. (2012) in an establishment located in Rio Grande do Sul, repulsive appearance was the third major cause of condemnation, representing $19.4 \%$, whereas the first was contamination (32\%). Total condemnation was not a prominent finding in Espírito Santo by SIF.

Table 8 shows the predominant changes that led to the condemnation of chicken carcasses by SIE and the respective number of condemnations per diagnosis. The major causes of condemnation were bruises/ fracture $(4.28 \%)$, contamination $(0.67 \%)$, cellulitis $(0.22 \%)$ and ascites $(0.12 \%)$. The highest percentage of condemnation was found for bruises/fractures, which represented $66.95 \%$ of condemned carcasses. These condemnation types were also observed by Dias et al. (2017), who showed that the most frequent in a slaughterhouse in Espírito Santo were bruises/fractures (47.83\%), followed by dermatosis (17.36\%) and, finally, contamination (17.24\%). For Rossi (2020), bruising is a great 
indicator that the handling from bird collection in the shed to their transport for slaughter is flawed and failing to respect the rules of animal welfare. As for contamination, the factors that promote the appearance of this technopathy according to SIE are different from those described by SIF, as the procedure is performed manually in the state service. Therefore, contamination in these establishments, may originate from a lack of training of operators for the applied techniques.

\section{Table 8}

Main causes of condemnation (partial and total) of broilers in establishments in Espírito Santo inspected by the State Inspection Service (SIE) between January 2018 and December 2019

\begin{tabular}{ccccccccc|}
\multirow{2}{*}{ Year } & \multicolumn{2}{c}{ Bruises } & \multicolumn{2}{c}{ Contamination } & \multicolumn{2}{c}{ Cellulitis } & \multicolumn{2}{c|}{ Ascites } \\
\cline { 2 - 8 } & $\mathrm{N}$ & $\%^{*}$ & $\mathrm{~N}$ & $\%^{*}$ & $\mathrm{~N}$ & $\%^{*}$ & $\mathrm{~N}$ & $\%^{*}$ \\
\hline 2018 & 527,342 & 63.94 & 111,266 & 13.49 & 31,873 & 3.86 & 13,282 & 1.61 \\
2019 & 860,819 & 69.97 & 109,449 & 8.90 & 38,446 & 3.13 & 27,476 & 3.33 \\
Total & $1,388,161$ & 66.95 & 220,715 & 11.20 & 70,319 & 3.50 & 40,758 & 2.47
\end{tabular}

* Calculation based on the number of condemned birds (partial and total).

Cellulitis is a disease with a multifactorial etiology. It is characterized by acute and diffuse purulent inflammation of the subcutaneous tissue that destroys tissue planes and may involve muscle layers and the development of perihepatitis, salpingitis and arthritis (Berchieri \& Macari, 2000). A noteworthy fact regarding this disease is that Escherichia coli will likely be present in most cases. Factors such as bird strain, nutrition, stocking rate, distance between feeders and drinkers, litter type, feed restrictions and lighting programs can affect the incidence and severity of this problem (Mendes \& Komiyama, 2011). These authors reported that the use of chelated minerals, especially zinc, associated with adequate supplementation of vitamin $E$, has yielded good results in the control of cellulitis in broilers.

It is important to emphasize that ascites is not a disease, but a pathological condition that is characterized by leakage of fluid from blood vessels and accumulation in the abdominal cavity. In the analysis carried out by Almeida et al. (2017), the authors observed its occurrence in $0.07 \%$ of the slaughtered birds. A similar result was found in the present study, where the cases corresponded to $0.12 \%$ of birds slaughtered and $1.98 \%$ of condemned chickens.

Regarding the financial impacts that each condemnation generates for slaughterhouses and, consequently, for the producer, a study by Maschio \& Raszl (2012) in a slaughterhouse located in the south of Brazil under SIF inspection concluded that, partial condemnations (considering those found in the current study) can cause losses of up to 664,840 thousand Brazilian reais a year. This is without considering dermatosis, as the study did not provide information on this condemnation and its impacts. In terms of total condemnations, an annual loss of 253,217 
thousand Brazilian reais is estimated if we disregard hemorrhagic viscera, which stood out in the present study as the prevailing cause of total condemnation. This information clearly shows that even though the percentages for some condemnations are relatively low (e.g., repulsive appearance: $0.09 \%$ ), the economic impact can be high. This was also noted by Maschio and Raszl (2012), who stressed that losses can reach $\mathrm{R} \$ 67,287$ annually. Therefore, a broad and skillful perspective within the slaughterhouse is mandatory, as are actions aimed at minimizing these occurrences. It noteworthy that the state of Espírito Santo lacks information on the economic impacts caused by condemnations, warranting further studies on the subject.

Overall, the partial and total condemnation rates of birds slaughtered at establishments inspected by the Federal Service were higher than the occurrences in establishments under State Inspection. Condemnations due to bruises/fractures and contamination were the most common by both Inspection Services. Almeida et al. (2017) grouped the causes of condemnations into pathological and non-pathological. Among the non-pathological causes (i.e., those that are directly related to handling labor and equipment) are bruises/fractures, contamination and repulsive appearance, which, in this study, amounted to $77.79 \%$ of the birds condemned (partially and totally) by SIF. In the case of SIE, bruises/fractures, contamination, as well as birds dead during transport are also included (3.66\%), which represent $81.81 \%$ of condemned birds (partial and total). These data are extremely relevant, as they demonstrate that condemnations can be drastically minimized through actions aimed at adjusting slaughtering techniques and equipment as well as training the employees. In this way, the handling of the chickens will not have negative impacts on production, and animal welfare will be ensured from their collection on the farm to their transport, slaughter and processing. Additionally, with these data, calculations can be performed to elucidate the team on how much is lost with each condemnation, raising awareness and thus reducing condemnations and increasing profits throughout the production chain (Gundim et al., 2015; Ebling \& Basurco, 2016).

\section{Conclusion}

The main causes of partial condemnations of broiler carcasses in the establishments inspected by the Federal Inspection Service in the state of Espírito Santo are bruises, dermatoses, contamination and myopathies. For the total condemnations, of the 977,361 cases, the presence of hemorrhagic viscera, malabsorption syndrome, ascites and repulsive appearances, together, represented 825,932 occurrences. In establishments inspected by SIE, the main causes of condemnation (partial and total) were bruises/fractures, contamination, cellulitis and ascites.

There was consistency in the reasons why these products were condemned. Bruises/ fractures and contamination were the most frequent causes by both Inspection Services (SIF and SIE), indicating a common problem in pre-slaughter management and on the slaughter and inspection lines, which should receive greater attention from the industry to minimize losses caused by the disposal of these products. 


\section{Acknowledgements}

Acknowledgements for their financial support National Council for Scientific and Technological Development (CNPq), National Council for the Improvement of Higher Education (CAPES) and the Espírito Santo Research Foundation (FAPES).

\section{References}

Almeida, T. J. de O., Assis, A. S. de., Mendonça, M., \& Rolim, M. B. de Q. (2017). Causas de condenação de carcaças de Gallus gallus domesticus em abatedouros frigoríficos sob Inspeção Federal no Nordeste do Brasil. Revista Medicina Veterinária (UFRPE), 11(4), 7-27. doi: 10.26605/medvet-n4-1958 Recuperado de http://www.journals.ufrpe.br/index. $\mathrm{php} / \mathrm{medicinaveterinaria/article/view/}$ 1958/482482581

Assis, B. V. de, Sabino, L. F., Silva, L. F. da\& Fontes, R. A. (2019). Prevalência de miopatia dorsal e miopatia peitoral profunda no abate de frangos em um abatedouro frigorífico localizado em Minas Gerais. Anais do Fórum Academico da Faculdade Vértice-Univértix, Matipó, MG, Brasil, 12. Recuperado de https:// fave.univertix.net/ wp-content/uploads/2019/11/R119-P1.pdf

Associação Brasileira de Proteína Animal (2019). Relatório anual. Recuperado de http://abpabr.org/wp-content/uploads/2019/08/ Relat\%C3\%B3rio-Anual-2019.pdf

Associação Brasileira de Proteína Animal (2020). Relatório anual. Recuperado de http://abpa-br.org/wp-content/uploads/ 2020/05/abpa_relatorio_anual_2020_ portugues_web.pdf
Associação dos Avicultores do Estado do Espírito Santo (2018). Perfil da avicultura capixaba. Recuperado de http://www. associacoes.org.br/images/PERFIL_ AVICULTURA_CAPIXABA_2017_-_2018. pdf

Berchieri, A. B., Jr., \& Macari, M. (2000). Doenças de aves. Campinas, SP: Facta.

Bilgilie, S. F., \& Hess, J. H. (2008). Miopatia peitoral profunda. Informativo traduzido do original Ross Tech 08/48, 2008. Aviagen Brasil: Tecnologia, 1(3), 1-6. Recuperado de https://www.yumpu.com/ pt/document/ read/10089560/miopatiapeitoral-profunda-aviagen

Decreto $n^{\circ}$ 9.013, de 29 de março de 2017. Diário da república $n^{\circ} 129$. Regulamenta a lei $n^{\circ} 1.2$, de 18 de dezembro de 1950, e a lei $n^{\circ} 7.889$, de 23 de novembro de 1989, que dispõe sobre a inspeção industrial e sanitária de produtos de origem animal. Recuperado de http://www.planalto. gov.br/ccivil_03/_ato2015-2018/2017/ decreto/d9013.htm

Dias, M. C., Borgo, A., Martinelli, F., Castro, H. E. W., Jefferson, G., \& Falçoni, F. M. de S. M. (2017). Principais causas e impacto econômico de condenações parciais de carcaças de frangos de corte em um matadouro frigorífico do sul do Espírito Santo. Revista Dimensão Acadêmica, 2(1), 20-34. doi: Recuperado de https://multivix. edu.br/wp-content/uploads/2018/09/ revista-dimensao-academica-v02-n01artigo-02.pdf

Ebling, P. D., \& Basurco, V. (2016). Análise das perdas econômicas oriundas da condenação de carcaças nos principais estados brasileiros produtores de frangos de corte. Revista Ciências Agroveterinárias 
e Alimento, 1(1), 1-11. Recuperado de http://revistas.faifaculdades.edu.br/index. php/cava/article/view/193

Ferreira, T. Z., Sesterhenn, R., \& Kindlein, L. (2012). Perdas econômicas das principais causas de condenações de carcaças de frangos de corte em matadourosfrigoríficos sob inspeção federal no Rio Grande do Sul. Acta Scientiae Veterinariae, 40(1), p. 1-6. Recuperado de http://www. ufrgs.br/actavet/40-1/PUB\% 010 21.pdf

Flemming, J. S., Janzen, S. A., \& Endo, M. A. (1999). Rendimento de carcaças em linhagens comerciais de frangos de corte. Archives Veterinary Science, 4 (1), p. 61-63. doi: 10.5380/avs.v4i1.3781 Recuperado de https://revistas.ufpr.br/ veterinary/article/view/3781/3022

Goscinscki, F. (2016). Análise dos índices de condenação de carcaças de frango em abatedouro da região norte paranaense. Higiene Alimentar, 30(260/261), p. 73-77. Recuperado de http://docs. bvsalud.org/biblioref/11/2721/260-261 sitecompressed-73-77.pdf

Gundim, L. F., Rodrigues, E. A., Blanca, W. T., Coleto, A. F., \& Medeiros, A. (2015). Causas de condenações de frangos de corte relacionadas a manejo e ambiência. Revista Enciclopédia Biosfera, 11(21), 515. Recuperado de https://www.conhecer.org. br/enciclop/2015b/agrarias/Causas\%20 de\%20condenacao\%20de\%20frangos. pdf

Hoving-Bolink, A. H., Kranen, R. W., Klont, R. E., Gerritsen, C. L. M., \& Greef, K. H. (2000). Fibre area and capillary supply in broiler breast muscle in relation to productivity and ascites. Meat Science, 56(4), 397402. doi: 10.1016/s0309-1740(00)00071-
1 Retrieved from https://pubmed.ncbi.nlm. nih.gov/22062170/\#: :text=Normally\%20 capillary\%20densities\%20decrease\%20 in,had\%20a\%20lower\%20capillary\%20 density

Instituto Brasileiro de Geografia e Estatística (2017). Censo agropecuário 2017. Recuperado de https://censoagro2017. ibge.gov.br/templates/censo_agro/ resultadosagro/pecuaria.html?localidade $=0 \&$ tema $=76579$

Joiner, K. S., Hamlin, G. A., Lien, A. R., \& Bilgili, S. F. (2014). Evaluation of capillary and myofiber density in the pectoralis major muscles of rapidly growing, high-yield broiler chickens during increased heat stress. Avian Diaseases, 58(3), 377382. doi: 10.1637/10733-112513-Reg.1 Retrieved from https:// pubmed.ncbi.nlm. nih.gov/25518431/

Kettlewell, P. J., \& Turner, M. J. B. (1985). A review of broiler chicken catching and transport systems. Journal of Agricultural Engineering Research, 31(2), 93-114. doi: 10.1016/00218634(85)90064-2 Retrieved from https:// www.sciencedirect.com/science/article/ abs/pii/0021 863485900642

Kotler, D. P. (2000) Cachexia. Annals of Internal Medicine, 133(1), 622-634. doi: 10.7326/0003-4819-133-8-20001017000015 Retrieved from https://www. acpjournals.org/doi/10.7326/0003-4819133-8-2000 10170-00015

Langer, R. O. (2007). Efeito do transporte na incidência de PSE (Pale, Soft, Exudative) e análogo ao DFD (Dark, Firm, Dry) em filés de frangos. Dissertação de mestrado, Universidade Estadual de Londrina, Londrina, PR, Brasil. Recuperado de http:// www.bibliotecadigital.uel.br/document/ ?view=vtls000123 367 
Leandro, N. S. M., Rocha, P. T., Stringhini, J. H., \& Fortes, R. M. (2001). Efeito do tipo de captura dos frangos de corte sobre a qualidade da carcaça. Recuperado de http://200.137.217.156/bitstream/ ri/12371/5/Artigo\%20-\%20Nadja\%20 Susana\%20Mogyca\%20Lenandro\%20 -\%202001.pdf

Lei n. 1.283, de 19 de dezembro de 1950. Dispõe sobre a inspeção industrial e sanitária dos produtos de origem animal. Recuperado de http://www.planalto.gov. br/ccivil_03/LEIS/L1283.htm

Lei n. 7.889, de 23 de novembro de 1989. Dispõe sobre a inspeção sanitária e industrial dos produtos de origem animal, e dá outras providências. Recuperado de http://www.planalto.gov.br/ccivil_03/LEIS/ L7889.htm

Maschio, M. M., \& Raszl, S. M. (2012). Impacto financeiro das condenações post-mortem parciais e totais em uma empresa de abate de frango. Atualidades Tecnológicas para Competitividade Industrial (e-tech), 1(1), 26-38. doi: 10.18624/E-TECH.VO 10.208 Recuperado de https://pdfs.se manticscholar.org/dfec/6912faa02b9be b73892d801c6c73bcd3daf.pdf

Mendes, A. A., \& Komiyama, C. M. (2011). Estratégias de manejo de frangos de corte visando qualidade de carcaça e carne. Revista Brasileira de Zootecnia, 40(1), 352-357. Recuperado de http://hdl. handle.net/ 11449/141114

Moreira, J., Mendes, A. A., Garcia, E. A., Oliveira, R. P.D., Garcia, R. G., \&Almeida, I. C. L. D. (2003). Avaliação de desempenho, rendimento de carcaça e qualidade da carne do peito em frangos de linhagens de conformação versus convencionais. Revista Brasileira de Zootecnia, 32(6), 1663-1673. doi: 10.1590/S1516-35982003000700016 Recuperado de https://www.scielo.br/ scielo.php?pid=S1516-35982003000 700016\&script=sci_abstract\&tlng=pt

Oliveira, A. A., Andrade, M. A., Armendaris, P. M., \& Bueno, P. H. S. (2016). Principais causas de condenação ao abate de aves em matadouros frigoríficos registrados no serviço brasileiro de inspeção federal entre 2006 e 2011. Revista Ciência Animal Brasileira, 17(1), 79-89. 10.1590/10896891v17i123020 Recuperado de https:// www.scielo.br/pdf/cab/v17n1/18096891-cab-17-01-0079.pdf

Paschoal, E. C., Otutumi, L. K., \& Silveira, A. P. (2012). Principais causas de condenações no abate de frangos de corte de um abatedouro localizado na região Noroeste do Paraná, Brasil. Arquivos de Ciências Veterinárias e Zoologia da UNIPAR, 15(2), 93-97. doi: 10.25110/arqvet.v15i2. 2012.4209 Recuperado de <https:// revistas.unipar.br/index.php/veterinaria/ article/view/4209/2618

Portaria $n^{\circ}$ 210, de 10 de novembro de 1998. Diário da república - seção I. Ministério da Agricultura, Pecuária e Abastecimento. Aprovar o regulamento técnico de Inspeção Tecnológica e HigiênicoSanitária de Carnes de Aves. Recuperado de http://extranet.agricultura.gov.br/ sislegis-consulta/consultarLegislacao. do ?operacao=visualizar\&id $=1129$

Rossi, G. A. (2020). Achados patológicos em abates de aves. Recuperado de http:// qualiflix.com.br/video-interna.php?id= 192927955 
Saif, Y. M. (2003). Diseases of poultry (13nd ed.). Ames: lowa State University Press.

Santiago,H.L.(2001).Impactofgeneticselection on skeletal muscle in meat-type poultry. Proceeding of the Virginia Polytechnic Institute e State University Graduate Seminar, Blackburg, Virginia, Estados Unidos. Retrieved from http://academic. uprm.edu/hsantiago/Impact\%20of\%20 Genetic\%20Selection\%20on\%20Skele tal\%20Muscle\%20ln\%20Meat\%20Type \%20Poultry.pdf

Santos, A. L. dos, Sakomura, N. K., Freitas, E. R., Fortes, C. M. L. S., Carrilho, E. N. V. M., \& Fernandes, J. B. K (2005). Estudo de crescimento, desempenho, rendimento de carcaça e qualidade de carne de três linhagens de frango de corte. Revista Brasileira de Zootecnia, 34(5), 589-1598. doi: 10.1590/S151635982005000500020 Recuperado de https://www.scielo.br/scielo.php?pid=S15 16-35982005000500020\&script $=$ sci_ab stract\&tlng $=p t$

Tinôco, I.D. F. (2001). Avicultura industrial:novos conceitos de materiais, concepções e técnicas construtivas disponíveis para galpões avícolas brasileiros. Brazilian Journal of Poultry Science, 3(1), 1-26. doi: 10.1590/S1516-635X2001000100001 Recuperado de https://www.scielo.br/ scielo.php?pid=S1516-635X2001000100 001\&script=sci_arttext\&tIng=pt 
